\title{
ANALISIS FAKTOR YANG BERHUBUNGAN DENGAN PENGGUNAAN IMPLAN OLEH AKSEPTOR KB DI PUSKESMAS RAWAT INAP SUKABUMI KOTA BANDAR LAMPUNG
}

\author{
Marlina \\ Jurusan Kebidanan Tanjungkarang \\ Email: marlinaturnip@yahoo.com
}

\begin{abstract}
Analisys Related Factors with Using of Implan by KB Acceptor in Sukabumi Inpatient Health Centers Bandar Lampung. As quantity, the number of Implan acceptor in working area of inpatient health centers because of many complaints i.e. $65 \%$ experiencing changes of menstruation pattern and $21 \%$ stated that the using of Implan which is used relatively long fertility effects. This research purpose to know the factors which related to the using of Implan by KB acceptor in Sukabumi inpatient health centers Bandar Lampung 2016. The research design is survey which is analytic with case control plan and qualitative research. This research population is women of childbearing age in Sukabumi inpatient health centers Bandar Lampung is 1.716 people. The sampling technique using proportional random sampling. Qualitative data analytic use the frequency distribution, chi-square and logistic regression. The result of research showed that there are relationships age $(p=0,002)$, education $(p=0,000)$, job $(p=0,012)$, numbers of children $(\mathrm{p}=0,000)$, birth spacing $(\mathrm{p}=0,004)$, attitude $(\mathrm{p}=0,000)$, cost $(\mathrm{p}=0,016)$, health workers skill $(\mathrm{p}=0,000)$, by using Implan for $\mathrm{KB}$ acceptor in inpatient health centers Sukabumi Bandar Lampung 2016. The result as multivariate shows that age is the most dominant variable related to ( $p=0,000$ and $\mathrm{OR}=6,39$ ). This research suggest to health workes need to increase knowledge about Implan for new $\mathrm{KB}$ acceptor candidate and couple. It can be done by giving information completely about Implan KB.
\end{abstract}

Keywords: Implan using, Family Planning Program (KB)

\begin{abstract}
Abstrak: Analisis Faktor yang Berhubungan dengan Penggunaan Implan oleh Akseptor KB di Puskesmas Rawat Inap Sukabumi Kota Bandar Lampung. Secara kuantitas, jumlah akseptor implan termasuk dalam kategori yang rendah dibandingkan akseptor non implan. Rendahnya akseptor KB implan di Wilayah Kerja Puskesmas Rawat Inap Sukabumi adalah dikarenakan munculnya banyak keluhan diantaranya $65 \%$ mengalami perubahan pola menstruasi dan $21 \%$ menyatakan implan yang digunakan efek kesuburan yang relatif lama. Tujuan penelitian ini adalah untuk diketahui faktor-faktor yang berhubungan dengan penggunaan implan pada akseptor KB di Puskemas Rawat Inap Sukabumi Kota Bandar Lampung Tahun 2016. Desain penelitian ini adalah survei yang bersifat analitik dengan rancangan case control dan penelitian kualitatif. Populasi penelitian ini adalah Wanita Usia Subur di Puskesmas Rawat Inap Sukabumi Kota Bandar Lampung sebanyak 1.716 orang. Jumlah sampel sebanyak 36 responden yang menggunakan implan di tahun 2015. Teknik sampling menggunakan proporsional random sampling. Analisis data kuantitatif menggunakan distribusi frekuensi, chi square dan regresi logistic. Hasil penelitian menunjukkan ada hubungan umur $(p=0,002)$, pendidikan $(p=0,000)$, pekerjaan $(p=0,012)$, jumlah anak $(p=0,000)$, jarak kelahiran $(p=0,004)$, sikap $(p=0,000)$, biaya $(p=0,016)$, keterampilan petugas kesehatan $(p=0,000)$, dengan penggunaan implan pada akseptor KB di Puskemas Rawat Inap Sukabumi Kota Bandar Lampung Tahun 2016. Hasil secara multivariate menunjukkan bahwa umur merupakan variabel paling dominan berhubungan $(p=0,000$ dan $\mathrm{OR}=6,39)$. Penelitian ini menyarankan kepada Petugas Kesehatan perlunya peningkatan pengetahuan tentang KB implan bagi calon akseptor KB baru dan pasangannya, yang dapat dilakukan melalui pemberian informasi secara lengkap tentang KB implan.
\end{abstract}

Kata kunci: Penggunaan implan, Keluarga Berencana

Menurut World Population Data Sheet 2013, Indonesia merupakan negara dengan estimasi jumlah penduduk terbanyak yaitu 249 juta dengan laju pertambahan penduduk 1,49\% per tahun yang artinya setiap tahun jumlah penduduk Indonesia bertambah 3-3,5 juta jiwa, bila tanpa pengendalian yang berarti atau tetap dengan pertumbuhan penduduk $1,49 \%$ per tahun, 
maka jumlah tersebut pada tahun 2010 akan terus bertambah dari 249 juta jiwa menjadi 293,7 juta jiwa pada tahun 2014 (BKKBN, 2008).

Salah satu program untuk mengontrol laju pertumbuhan penduduk dan menurunkan angka kematian ibu (AKI) yakni melalui program Keluarga Berencana (KB). Sasaran program KB diantaranya adalah peningkatan prevalensi pemakaian kontrasepsi (Contraseptive Produktif Rate/CPR) menjadi $65 \%$, penurunan Pasangan Usia Subur/PUS tidak mau punya anak tetapi tidak mau ber-KB (Unmet Need) menjadi 5,5\%, dan peningkatan penggunaan Metode Kontrasepsi Jangka Panjang (MKJP) menjadi 26,03\%. Pada tahun 2014 target penggunaan MKJP yang diharapkan sebesar 26,03\% justru masih berada di angka 22,03\% (BKKBN, 2013).

Salah satu alat kontrasepsi permanen yang bersifat sementara dan memiliki efektifitas yang tinggi dengan prosedur pemasangan yang tidak memerlukan waktu yang lama yaitu alat kontrasepsi implan, namun penggunaan implan masih sangat jarang (Hartanto, 2008). Berdasarkan data BKKBN Provinsi Lampung tahun 2013 jumlah peserta KB aktif sebanyak 750.273 jiwa dengan rincian pengguna IUD sebanyak $98.286(13,1 \%)$ akseptor, tubektomi sebanyak $30.761(4,10 \%)$ akseptor, vasektomi sebanyak $3.677(0,49 \%)$ akseptor, implan sebanyak $118.544(15,8 \%)$ akseptor (BKKBN Provinsi Lampung, 2013).

Puskesmas Rawat Inap Sukabumi tahun 2014, memiliki PUS sebanyak 2.860 jiwa dengan jumlah peserta KB aktif sebesar 1.780 jiwa, dimana pengguna IUD sebesar $0,06 \%$ akseptor, implan sebesar 1,46\% akseptor, sedangkan untuk metode non MKJP yaitu: suntikan sebesar 25,6\% akseptor, pil sebesar $21,7 \%$ akseptor, dan kondom sebesar 10,3\% akseptor (Puskesmas Rawat Inap Sukabumi, 2015). Tahun 2015 jumlah peserta KB aktif Puskesmas Rawat Inap Sukabumi sebanyak 1.716 (70,5\%) jiwa, namun penggunaan metode kontrasepsi khususnya implan dan IUD mengalami penurunan dengan rincian pengguna IUD sebesar $0,7 \%$ akseptor, implan sebesar $1,2 \%$ akseptor, tubektomi sebesar $0,00 \%$ akseptor, dan vasektomi sebesar $0,00 \%$ dan pengguna metode non MKJP yaitu: suntikan $37,2 \%$ akseptor, pil sebesar $21,8 \%$ akseptor, dan kondom sebesar 9,3\% akseptor (Puskesmas Rawat Inap Sukabumi, 2015).

Rendahnya akseptor KB dalam penggunaan implan di Wilayah Kerja Puskesmas Rawat Inap Sukabumi adalah munculnya banyak keluhan, tercatat dari 38 akseptor KB terdapat sebanyak $25(65,0 \%)$ mengalami perubahan pola menstruasi, sebanyak 8 (21\%) menyatakan implan yang digunakan tidak memberikan efek. Kemungkinan tersebut terjadi karena petugas kesehatan salah memasukkan implan. Kesalahan posisi sulit untuk dideteksi karena tidak semua implan dapat terdeteksi oleh sinar-X. Strategi peningkatan penggunaan MKJP dengan implan dirasa kurang begitu berhasil, hal ini dapat dilihat dari jumlah pengguna alat kontrasepsi implan yang dari tahun ketahun semakin menurun. Adapun beberapa faktor yang diduga memiliki kontribusi didalam penggunaan implan, antara lain faktor yang harus dipertimbangan adalah status kesehatan individu, efek samping, potensial kegagalan, umur, paritas, jarak kehamilan, pendidikan, pekerjaan, biaya, jarak ke tempat pelayanan kesehatan, dan dukungan suami didalam ber-KB yang mempengaruhi keputusan calon akseptor KB, serta sistem pencatatan dan pelaporan yang dilakukan baik di tingkat BPS ataupun pelayanan kesehatan lainnya. Berdasarkan latar belakang diatas maka peneliti tertarik untuk melakukan penelitian tentang "Analisis Faktor yang Berhubungan dengan Penggunaan Implan oleh Akseptor KB di Puskesmas Rawat Inap Sukabumi Kota Bandar Lampung Tahun 2016."

\section{METODE PENELITIAN}

Jenis penelitian yang akan digunakan adalah penelitian kuantitatif dengan pendekatan case control. Penelitian ini akan menilai faktorfaktor yang berhubungan dengan penggunaan KB Implan dengan cara menentukan kelompok kasus dan kelompok kontrol, kemudian mengukur besarnya frekuensi kejadian pengguna KB Implan pada kedua kelompok. Waktu Penelitian Mei-September 2016. Populasi ada penelitian ini atau objek yang diteliti adalah WUS. Sampel dalam penelitian ini sebanyak 36 Responden. Sampel Kelompok kontrol adalah ibu yang tidak menggunakan KB Implan di Puskesmas Sukabumi pada tahun 2016 sebanyak 36 responden. 
HASIL

\section{A. ANALISIS UNIVARIAT}

Tabel 1. Distribusi Frekuensi Akseptor KB berdasarkan Umur, Pendidikan, Pekerjaan, Jumlah Anak, Jarak Kelahiran, Biaya, Jarak Pelayanan

\begin{tabular}{lcc}
\hline Umur & $\mathbf{n}$ & $\boldsymbol{\%}$ \\
\hline $20-35$ tahun & 34 & 47.2 \\
\hline$<20$ atau $>35$ tahun & 38 & 52.8 \\
\hline Pendidikan & & \\
\hline Tinggi & 24 & 33.3 \\
\hline Rendah & 48 & 66.7 \\
\hline Pekerjaan & & \\
\hline Bekerja & 23 & 31.9 \\
\hline Tidak bekerja & 49 & 68.1 \\
\hline Jumlah Anak & & \\
\hline$\leq 2$ anak & 24 & 33.3 \\
\hline$>2$ anak & 48 & 66.7 \\
\hline Jarak Kelahiran & & \\
\hline$\geq 2$ tahun & 24 & 33.3 \\
\hline$<2$ tahun & 48 & 66.7 \\
\hline Biaya & & \\
\hline Mampu & 23 & 31.9 \\
\hline Tidak mampu & 49 & 68.1 \\
\hline Jarak Pelayanan & & \\
\hline Dekat & 48 & 66.7 \\
\hline Jauh & 24 & 33.3 \\
\hline
\end{tabular}

Berdasarkan tabel 1 diketahui bahwa distribusi akseptor yang berusia 20-35 tahun lebih banyak $(47,2 \%)$ dibandingkan dengan akseptor yang berusia $<20$ atau $>35$ tahun $(52,8 \%)$; pendidikan akseptor KB lebih didominasi akseptor $\mathrm{KB}$ dengan tingkat pendidikan yang rendah yaitu $66,7 \%$ dibandingkan akseptor dengan pendidikan tinggi (33,3\%); proporsi akseptor KB dengan status tidak bekerja lebih banyak (68.1\%) dibandingkan dengan akseptor $\mathrm{KB}$ dengan status bekerja (31.9\%); proporsi akseptor KB dengan jumlah anak $\leq 2$ lebih sedikit jumlahnya yaitu (33.3\%) dibandingkan dengan akseptor $\mathrm{KB}$ dengan jumlah anak >2 (66.7\%); proporsi akseptor KB dengan jarak kelahiran $\geq 2$ tahun lebih sedikit jumlahnya yaitu $(33,3 \%)$ dibandingkan dengan akseptor KB dengan jarak kelahiran $<2$ tahun $(66,7 \%)$; proporsi akseptor yang merasa tidak mampu lebih banyak $(68,1 \%)$ dibandingkan dengan akseptor KB yang merasa mampu dengan biaya penggunaan implan (31,9\%); proporsi akseptor yang jarak untuk mendapatkan pelayanan KB dalam kategori dekat lebih banyak $(66,7 \%)$ dibandingkan dengan akseptor KB yang merasa jarak pelayanan KB dalam kategori jauh $(33,3 \%)$.

\section{B. ANALISIS BIVARIAT}

Tabel 2. Hubungan Umur, Pendidikan, Pekerjaan, Jumlah Anak, Jarak Kelahiran, Biaya dan Jarak Pelayanan dengan Penggunaan Implan

\begin{tabular}{|c|c|c|c|c|c|c|c|c|}
\hline \multirow{3}{*}{ Variabel } & \multicolumn{4}{|c|}{ Penggunaan Implan } & \multirow{2}{*}{\multicolumn{2}{|c|}{ Total }} & \multirow{3}{*}{$p$-value } & \multirow{3}{*}{$\begin{array}{c}O R \\
95 \% \mathrm{CI}\end{array}$} \\
\hline & \multicolumn{2}{|c|}{ Kasus } & \multicolumn{2}{|c|}{ Kontrol } & & & & \\
\hline & $\mathbf{n}$ & $\%$ & $\mathbf{n}$ & $\%$ & $\mathbf{n}$ & $\%$ & & \\
\hline \multicolumn{9}{|l|}{ Umur } \\
\hline 20-35 tahun & 13 & 37.1 & 8 & 62.9 & 20 & 27.7 & \multirow{2}{*}{0.002} & 2.29 \\
\hline$<20$ atau $>35$ tahun & 23 & 20.5 & 28 & 79.5 & 51 & 72.3 & & $(1.36-3.84)$ \\
\hline \multicolumn{9}{|l|}{ Pendidikan } \\
\hline Tinggi & 29 & 44.9 & 7 & 55.1 & 36 & 50 & \multirow{2}{*}{0.000} & 3.62 \\
\hline Rendah & 7 & 18.3 & 29 & 81.7 & 36 & 50 & & $(2.13-6.15)$ \\
\hline \multicolumn{9}{|l|}{ Pekerjaan } \\
\hline Bekerja & 28 & 77.7 & 22 & 61.1 & 50 & 69.4 & \multirow{2}{*}{0.012} & 1.98 \\
\hline Tidak Bekerja & 8 & 22.3 & 14 & 38.8 & 22 & 30.6 & & $(1.18-3.32)$ \\
\hline \multicolumn{9}{|l|}{ Jumlah Anak } \\
\hline$\leq 2$ anak & 14 & 38.8 & 21 & 58.3 & 35 & 48.6 & \multirow{2}{*}{0.000} & 2.64 \\
\hline$>2$ anak & 22 & 61.2 & 15 & 41.7 & 37 & 51.4 & & $(1.57-4.44)$ \\
\hline \multicolumn{9}{|l|}{ Jarak Kelahiran } \\
\hline$\leq 2$ tahun & 26 & 72.3 & 14 & 38.8 & 40 & 55.5 & \multirow{2}{*}{0.004} & 2.28 \\
\hline$>2$ tahun & 10 & 27.7 & 22 & 61.2 & 32 & 45.5 & & $(1.33-3.90)$ \\
\hline \multicolumn{9}{|l|}{ Biaya } \\
\hline Mampu & 26 & 72.2 & 14 & 38.3 & 40 & 55.5 & \multirow{2}{*}{0.016} & 1.97 \\
\hline Tidak mampu & 10 & 18.8 & 22 & 61.7 & 32 & 45.5 & & $(1.16-3.35)$ \\
\hline \multicolumn{9}{|l|}{ Jarak Pelayanan } \\
\hline Dekat & 31 & 86.1 & 25 & 69.4 & 56 & 77.7 & \multirow{2}{*}{0.000} & 3.39 \\
\hline Jauh & 5 & 23.9 & 11 & 30.6 & 16 & 22.3 & & $(1.93-5.96)$ \\
\hline
\end{tabular}




\section{ANALISIS MULTIVARIAT}

Tabe1 3. Hasil Uji Multivariat Tahap Kelima

\begin{tabular}{lcrrrr}
\hline \multirow{2}{*}{ Variabel } & \multirow{2}{*}{ B } & \multirow{2}{*}{ Sig. } & \multirow{2}{*}{$\operatorname{Exp(B)}$} & \multicolumn{2}{c}{\begin{tabular}{c} 
95.0\% C.I.for \\
\cline { 4 - 6 }
\end{tabular}} \\
\cline { 5 - 6 } & & & & Lower & Upper \\
\hline Umur & 0.958 & 0.005 & 2.608 & 1.333 & 5.100 \\
\hline $\begin{array}{l}\text { Jarak } \\
\text { Kelahiran }\end{array}$ & 0.674 & 0.057 & 2.048 & 1.303 & 5.381 \\
\hline Constant & -2.702 & 0.000 & .067 & & \\
\hline
\end{tabular}

Berdasarkan tabel 3 diketahui bahwa dari 2 variabel yang berhubungan dengan penggunaan implan, sudah tidak terdapat variabel yang memiliki nilai $p>0,05$, sehingga tidak ada variabel yang harus dikeluarkan dari model. Hasil akhir multivariat dapat diketahui bahwa dari dua faktor yang berhubungan dengan penggunaan implan (Umur dan Jarak Kelahiran) dan umur merupakan faktor yang paling dominan berhubungan dengan penggunaan implan di Puskesmas Rawat Inap Sukabumi Kota Bandar Lampung ( $p=0,000$ dan OR; 6,39).

\section{PEMBAHASAN}

\section{A. ANALISIS UNIVARIAT}

\section{Umur}

Hasil penelitian menunjukkan bahwa akseptor implan lebih banyak digunakan oleh ibu yang berusia $<20$ atau $\geq 35$ tahun. Data ini menggambarkan bahwa penggunaan implan dijadikan pilihan sebagai salah satu metode $\mathrm{KB}$ Jangka Panjang bagi ibu yang berusia $>35$ tahun dan menganggap di usia ini ibu sudah enggan untuk memiliki anak lagi sehingga kontrasepsi implan dijadikan sebagai pilihan.

Hasil analisis ini tidak sejalan dengan teori yang ada, dimana secara konseptual dijelaskan Suratun (2009) bahwa penggunaan implan sangat dianjurkan pada masa periode umur istri antara 20-35 tahun dengan tujuan untuk menjarangkan jarak kelahiran, sedangkan untuk WUS berumur $<20$ tahun dianjurkan untuk menunda kehamilan. Menurut Hartanto (2008) pada usia ini sebaiknya WUS menunda kehamilannya, dengan kontrasepsi yang dianjurkan adalah pemakaian pil $\mathrm{KB} /$ kontrasepsi oral. WUS yang berusia $\geq 35$ tahun dianjurkan menggunakan kontrasepsi mantap dengan MOW.

Proporsi usia pengguna implan dan non implan pada penelitian ini justru berbeda jauh dengan penelitian Suprida (2013) pada penelitian yang berjudul "Hubungan antara pendidikan dan umur ibu dengan pemilihan kontrasepsi implan di BPS Rachmi Palembang Tahun 2013, proporsi responden menurut kategori umur muda $\leq 20$ tahun yang mengunakan kontrasepsi implan berjumlah 73 orang $(80,2 \%)$ lebih besar dari proporsi responden umur tua $>35$ tahun yang mengunakan kontrasepsi implan berjumlah 18 responden $(19,8 \%)$.

\section{Pendidikan}

Hasil penelitian menunjukkan bahwa pendidikan akseptor $\mathrm{KB}$ lebih didominasi akseptor KB dengan tingkat pendidikan yang rendah yaitu $66.7 \%$ dibandingkan akseptor dengan pendidikan tinggi $(33,3 \%)$. Artinya sebagian ibu yang menjadi responden adalah ibu dengan pendidikan tidak tamat SD atau SMP.

Hal ini tidak sejalan dengan konsep yang dikemukan oleh Depkes (1999), bahwa penggunaan alat kontrasepsi sangat diperlukan pentingnya komunikasi, informasi dan edukasi, sehingga KB akan lebih mudah diterima jika riwayat pasien tidak buta huruf dan telah wajib belajar, dengan kata lain bahwa pendidikan memiliki peranan yang penting dalam menentukan kualitas manusia, jika pendidikan lebih tinggi maka akan membuat pemahaman yang lebih baik menggunakan kontarsepsi (Manuaba, 2005).

\section{Pekerjaan}

Hasil penelitian menunjukkan bahwa kondisi yang ada di Puskesmas rawat inap Sukabumi lebih banyak yang tidak bekerja dibandingkan dengan yang bekerja.

Penelitian ini sejalan dengan penelitian Fienalia (2012) yang dilakukan kepada 277 responden menunjukkan bahwa proporsi responden yang tidak bekerja sebanyak 152 $(54,8 \%)$ sedangkan proporsi responden yang bekerja sebanyak $125(45,13 \%)$ data ini menunjukkan bahwa ibu yang bekerja lebih banyak dibandingkan dengan yang tidak bekerja.

\section{Jumlah Anak}

Hasil penelitian menunjukkan bahwa sasaran penelitian ini lebih didominasi oleh responden yang memiliki anak lebih dari 2 (dua). Hasil ini dikarenakan responden sudah merasa cukup dengan memiliki anak dua sehingga dirasa tidak perlu lagi memiliki anak ketiga dan seterusnya.

Secara konseptual hasil uji univariat tidak didukung dengan teori, dimana teori dijelaskan bahwa jumlah anak merupakan suatu kondisi yang berkaitan dengan kesehatan reproduksi wanita. Menurut Prawirohardjo (2011) biasanya ibu yang telah memiliki anak kedua atau lebih biasanya akan lebih berpengalaman dalam 
memilih kontrasepsi KB. Sebaliknya jika masih anak pertama, umumnya calon akseptor $\mathrm{KB}$ masih belum paham dalam memilih alat kontrasepsi yang akan digunakan. BKKBN (2009) mengatakan bahwa paritas ibu dengan $\leq 2$ anak sangat dianjurkan untuk menggunakan kontrasepsi implan untuk menurunkan resiko kematian maternal, sedangkan paritas dengan $>2$ anak memiliki resiko kematian maternal lebih besar, sehingga penggunaan kontrasepsi mantap sangat dianjurkan.

\section{Jarak Kelahiran}

Dari hasil diketahui bahwa masih banyak ibu yang belum mengetahui tentang pentingnya menjarangkan kelahiran anak dengan rentang waktu minimal $\leq 2$ tahun, menjarangkan kelahiran ini salah satunya dapat dilakukan dengan menggunakan kontrasepsi.

Hasil ini sejalan dengan konsep yang dikemukakan oleh Depkes (1999), bahwa kontrasepsi sebaiknya dipilih oleh wanita yang jarak kelahirannya $\leq 2$ tahun dengan tujuan untuk menjarangkan jarak kehamilan/ kelahiran, dikarenakan jarak kelahiran $\leq 2$ tahun termasuk kedalam 4 terlalu, pada jarak kelahiran ini sangat dianjurkan penggunaan kontrasepsi dengan implan untuk mengatur jarak kelahiran selanjutnya. Sedangkan jarak kelahiran $\geq 2$ tahun adalah jarak kehamilan yang ideal, dikarenakan pada masa itu alat reproduksi di dalam tubuh seorang WUS sudah kembali bereproduksi dengan baik setelah melahirkan anak.

Hasil penelitian ini sejalan dengan penelitian Suprida (2013) yang melakukan penelitian dengan isu yang sama yakni tentang implan, sasaran penelitian adalah 81 responden dimana dari jumlah tersebut terdistribusi sebanyak $15(19,2 \%)$ responden memiliki jarak kelahiran anakan yang $<2$ tahun sedangkan jarak kelahiran $>2$ tahun sebanyak 66 (81\%). Proporsi ini menunjukkan kesadaran responden untuk menjarangkan jumlah anak yang dapat diimplementasikan melalui kepesertaannya dalam KB salah satunya dengan menggunakan implan.

\section{Biaya}

Hasil penelitian menunjukkan bahwa biaya menunjukkan kemampuannya berkaitan dengan kondisi sosial ekonomi dimana hasil penelitian menunjukkan bahwa proporsi akseptor yang merasa tidak mampu lebih banyak $(68,1 \%)$ dibandingkan dengan akseptor KB yang merasa mampu dengan biaya penggunaan implan $(31,9 \%)$. Biaya yang diukur dalam penelitian ini adalah kemampuan akseptor untuk membayar penggunaan kontrasepsi implan dengan sejumlah uang Rp. 300.000.

Hal ini tidak sejalan dengan teori yang dikemukakan oleh BKKBN (2009) bahwa pada dasarnya biaya mempengaruhi keikutsertaan calon akseptor KB untuk mendapatkan pelayanan $\mathrm{KB}$, karena semakin mahal harga kontrasepsi yang ditawarkan semakin terbatas pula akseptor untuk mendatangi pelayanan kontrasepsi KB tertentu.

Penelitian Suprida (2013) yang menjelaskan bahwa tingkat sosial ekonomi dapat mendorong seseorang untuk memilih atau menggunakan pelayanan kesehatan. Hasil penelitiannya menjelaskan proporsi sebanyak 47 $(49,0 \%)$ yang merasa tidak sanggup dengan biaya yang harus keluarkan untuk mendapatkan pelayanan kesehatan dan $49(51,0 \%)$ merasa sanggup untuk membiayai kebutuhan kesehatanya. Kesanggupan responden untuk membiayai kebutuhan kesehatannya salah satunya adalah penggunaan implan, sampai saat ini pelayanan kesehatan telah menjadi perhatian pemerintah, sehingga banyak yang tidak dipungut biaya namun pada prakteknya ada beberapa program yang pelayananya sudah gratis sehingga seharusnya masalah biaya tidak menjadi masalah seseorang untuk mendapatkan pelayanan kesehatan, atau kalaupun tidak gratis tetapi biaya dari pelayanan tersebut umumnya sangat terjangkau dan murah. Pelayanan pemasangan implan adalah salah satu pelayanan KB yang nilainya sangat terjangkau, jadi secara faktual seharusnya masalah biaya tidak menjadi hambatan seseorang untuk dapat menggunakan implan.

\section{Jarak ke Tempat Pelayanan}

Hasil penelitian menunjukkan bahwa proporsi akseptor yang jarak untuk mendapatkan pelayanan KB dalam kategori dekat lebih banyak (66,7\%), hal ini dikarenakan pelayanan KB dapat menjangkau jauh kepada masyarakat dengan kebijakan lain yang mendukung program ini seperti adanya Poskesdes, penempatan bidan desa, pelayanan KB di Posyandu dan lain sebagainya.

Hasil di atas didukung dengan teori yang dikemukakan oleh Saifuddin (2003) pada umumnya pasien-pasien akan mencari tempat pertolongan kesehatan ke fasilitas kesehatan yang berlokasi di dekat tempat tinggal mereka bila karena alasan tertentu mereka mendatangi tempat pelayanan yang jauh maka petugas klinik tersebut harus mampu membantu dan menjelaskan fasilitas kesehatan terdekat yang dapat memberikan perawatan dan pelayanan kesehatan 
lanjutan. Selain itu Akses pelayanan yang efektif hanya dapat menjamin jika pelayanan terjangkau secara finansial, dianggap sesuai dan dapat diterima oleh wanita sebagai pengguna pelayanan. Akses pelayanan yang terlalu jauh $>1$ $\mathrm{km}$ akan mempersulit wanita untuk mendapatkan pelayanan, sebaiknya jarak minimal $\leq 1 \mathrm{~km}$ dari rumah akseptor KB (Depkes RI, 2009).

Penelitian ini sejalan dengan peneltian Suprida (2013) yang menggambarkan proporsi dari 83 responden diketahui respondenyang memiliki jarak pelayanan kesehatan dekat yaitu sebanyak 52 orang $(62,7 \%)$.

\section{B. ANALISIS BIVARIAT}

\section{Hubungan Umur dengan Penggunaan Implan}

Hasil uji statistik membuktikan ada hubungan umur dengan penggunaan implan pada akseptor KB di Puskesmas Rawat Inap Sukabumi Kota Bandar Lampung Tahun $2016(p=0,002)$.

Karakteristik usia menjadi salah satu pertimbangan calon akseptor dalam menentukan penggunaan implan. Karena penggunaan implan dilakukan atas dasar pertimbangan tertentu sesuai dengan kebutuhan, keamanan dan kenyamanannya. Seseorang menunda kehamilan atau tidak ingin hamil lagi jika masih berada pada rentang usia yang memberikan risiko terhadap kehamilan dan persalinan. Pengertian umur dijelaskan oleh Depkes (2007) sebagai lamanya waktu hidup sejak dilahirkan. Umur mempengaruhi calon akseptor dalam penerimaan dan pengambilan keputusan dalam memilih alat kontrasepsi yang akan digunakan. Perencanaan keluarga berencana untuk menuju keluarga kecil bahagia dan sejahtera di bagi atas 3 masa dari usia reproduksi istri yaitu masa menunda kehamilan jika berusia $<20$ tahun dianjurkan menggunakan kontrasepsi oral dengan PIL KB, masa mengatur kesuburan jika berusia antara 2035 tahun pada masa ini kontrasepsi yang dianjurkan adalah implan dan masa mengakhiri kesuburan (tidak ingin hamil lagi), jika periode umur istri >35 tahun, pada masa ini dianjurkan menggunakan metode kontrasepsi mantap jika anak ibu $\geq 2$ anak.

Hasil penelitian ini juga sejalan dengan penelitian Suprida (2013) yang berjudul "Hubungan antara pendidikan dan umur ibu dengan pemilihan kontrasepsi implan di BPS Rachmi Palembang Tahun 2013”, proporsi responden menurut kategori umur muda $\leq 20$ tahun yang mengunakan kontrasepsi implan berjumlah 73 orang $(80,2 \%)$ lebih besar dari proporsi responden umur tua $>35$ tahun yang mengunakan kontrasepsi implan berjumlah 18 responden $(19,8 \%)$. Hasil uji Chi-Square pada penelitian ini menunjukan ada hubungan yang bermakna dengan dengan pemakaian kontrasepsi implan karena $p$ value $=0.025$ lebih kecil dari $\alpha=0,05$, dan hasil hipotesis awal yang menyatakan bahwa ada hubungan antara umur ibu terhadap pemilihan kontrasepsi implan.

\section{Hubungan Tingkat Pendidikan dengan Penggunaan Implan}

Hasil uji statistik membuktikan ada hubungan pendidikan dengan penggunaan implan pada akseptor KB di Puskesmas Rawat Inap Sukabumi Kota Bandar Lampung Tahun 2016 $(p=0,000)$, dengan peluang 3,6 kali pada akseptor yang berpendidikan tinggi dibandingkan akseptor yang berpendidikan rendah.

Hasil penelitian ini menunjukkan bahwa secara proporsi responden di Puskesmas Rawat Inap Sukabumi Kota Bandar Lampung yang menjadi responden dalam penelitian ini lebih banyak yang berpendidikan rendah dibandingkan responden yang berpendidikan tinggi. Hal ini dapat menjadi kendala tersendiri dalam memberikan penyadaran dan informasi tentang implan. Hasil penelitian tersebut membuktikan bahwa semakin rendah pendidikan responden maka kemungkinan tidak menggunakan implan semakin besar dan demikian pula sebaliknya karena semakin tinggi tingkat pendidikannya maka semakin luas wawasan dan informasi yang diperoleh berkaitan dengan informasi dan meningkatkan pemahaman tentang implan.

\section{Hubungan Pekerjaan dengan Penggunaan Implan}

Hasil uji statistik membuktikan ada hubungan pekerjaan dengan penggunaan implan pada akseptor KB di Puskesmas Rawat Inap Sukabumi Kota Bandar Lampung Tahun 2016 $(p=0,012)$ dan akseptor yang bekerja mempunyai peluang 1,9 kali untuk menggunakan implan dibanding akseptor yang tidak bekerja.

Pada penelitian ini memberikan gambaran tentang karakteristik ibu hamil di Puskesmas Rawat Inap Sukabumi Kota Bandar Lampung dalam statusnya bekerja atau tidak bekerja yang turut memberikan implikasi terhadap penggunaan implan. Hasil penelitian yang kontradiktif dengan teori disebabkan karena setiap individu mempunyai perbedaan struktur sosial, gaya hidup dan pola penggunaan pelayanan kesehatan. Secara ekonomi, pekerjaan dapat meningkatkan kemampuan pendapatan seseorang yang memudahkan dalam membiayai kesehatannya. 


\section{Hubungan Jumlah Anak dengan Penggunaan Implan}

Hasil uji statistik membuktikan ada hubungan jumlah anak dengan penggunaan implan pada akseptor KB di Puskesmas Rawat Inap Sukabumi Kota Bandar Lampung Tahun $2016(p=0,000)$ dan akseptor yang mempunyai anak $\leq 2$ berpeluang 2,6 kali untuk menggunakan implan dibanding akseptor yang anaknya lebih dari $2(\mathrm{OR}=2,64)$.

Hasil penelitian sejalan dengan teori yang dikemukakan oleh Prawirohardjo (2011) bahwa paritas adalah jumlah anak yang dimiliki ibu, biasanya ibu yang telah memiliki anak kedua atau lebih biasanya akan lebih berpengalaman dalam memilih alat kontrasepsi KB. Sebaliknya jika masih anak pertama, umumnya calon akseptor KB masih belum paham dalam memilih alat kontrasepsi yang akan digunakan. Menurut BKKBN (2009) penggunaan implan pada paritas 1-2 anak sangat dianjurkan untuk menurunkan resiko kematian maternal.

Hasil penelitian ini juga mendukung penelitian yang dilakukan Fienalia (2012) yang berjudul "faktor-faktor yang berhubungan dengan pemilihan Metode Kontrasepsi Jangka Panjang (MKJP) di Wilayah Kerja Puskesmas Pancoran Mas Kota Depok Tahun 2012" dari jumlah terhadap akseptor KB menyatakan bahwa ada hubungan yang signifikan antara jumlah anak dengan penggunaan implan, dimana responden yang memiliki anak lebih dari 3 memiliki peluang 3,9 kali lebih besar untuk menggunakan implan dibandingkan dengan responden/ibu yang memiliki anak 0-2 orang.

\section{Hubungan Jarak Kelahiran dengan Penggunaan Implan}

Hasil uji statistik membuktikan ada hubungan jarak kelahiran dengan penggunaan implan pada akseptor KB di Puskesmas Rawat Inap Sukabumi Kota Bandar Lampung Tahun $2016(p=0,004)$. Akseptor yang jarak kelahiran anaknya $\leq 2$ tahun berpeluang 2,2 kali untuk menggunakan implan dibanding akseptor yang jarak kelahiran anaknya lebih dari 2 tahun $(\mathrm{OR}=2,28)$.

Penelitian tersebut sejalan dengan teori yang dikemukakan oleh Depkes (2007), bahwa kontrasepsi sebaiknya dipilih oleh wanita yang jarak kelahirannya $\leq 2$ tahun dengan tujuan untuk menjarangkan jarak kehamilan/kelahiran, dikarenakan jarak kelahiran $\leq 2$ tahun termasuk kedalam 4 terlalu, pada jarak kelahiran ini sangat dianjurkan penggunaan kontrasepsi dengan implan untuk mengatur jarak kelahiran selanjutnya. Sedangkan jarak kelahiran $>2$ tahun adalah jarak kehamilan yang ideal, dikarenakan pada masa itu alat reproduksi di dalam tubuh seorang WUS sudah kembali bereproduksi dengan baik setelah melahirkan anak.

\section{Hubungan Biaya dengan Penggunaan Implan}

Hasil uji statistik membuktikan ada hubungan biaya dengan penggunaan implan pada akseptor KB di Puskesmas Rawat Inap Sukabumi Kota Bandar Lampung Tahun $2016(p=0,016)$. Kemampuan seseorang dalam membiayai kesehatannya tidak terlepas dari kondisi sosial ekonomi yang diukur dalam penelitian ini adalah pendapatan keluarga, bila kemampuan pendapatan keluarga rendah akan berakibat pula terhadap kondisi keluarga secara umum.

Hasil penelitian tersebut sejalan dengan teori yang dikemukakan oelh BKKBN (2009) bahwa pada dasarnya biaya mempengaruhi keikutsertaan calon akseptor KB untuk mendapatkan pelayanan $\mathrm{KB}$, karena semakin mahal harga kontrasepsi yang ditawarkan semakin terbatas pula akseptor untuk mendatangi pelayanan kontrasepsi $\mathrm{KB}$ tertentu.

\section{Hubungan Jarak Pelayanan dengan Penggunaan Implan}

Hasil uji statistik membuktikan ada hubungan pengetahuan dengan penggunaan implan pada akseptor KB di Puskesmas Rawat Inap Sukabumi Kota Bandar Lampung Tahun $2016(p=0,000)$.

Hasil penelitian didukung dengan teori yang dikemukakan oleh Saifuddin (2003) pada umumnya pasien-pasien akan mencari tempat pertolongan kesehatan ke fasilitas kesehatan yang berlokasi di dekat tempat tinggal mereka bila karena alasan tertentu mereka mendatangi tempat pelayanan yang jauh maka petugas klinik tersebut harus mampu membantu dan menjelaskan fasilitas kesehatan terdekat yang dapat memberikan perawatan dan pelayanan kesehatan lanjutan. Selain itu akses pelayanan yang efektif hanya dapat menjamin jika pelayanan terjangkau secara finansial, dianggap sesuai dan dapat diterima oleh wanita sebagai pengguna pelayanan. Akses pelayanan yang terlalu jauh $>1$ $\mathrm{km}$ akan mempersulit wanita untuk mendapatkan pelayanan sebaiknya jarak minimal $\leq 1 \mathrm{~km}$ dari rumah akseptor KB (Depkes RI, 2009).

\section{ANALISIS MULTIVARIAT}

Dari hasil keseluruhan proses analisis multivariat yang telah dilakukan dapat disimpulkan bahwa dari beberapa faktor yang 
berhubungan dengan penggunaan implan terdapat faktor yang memiliki hubungan paling dominan dengan penggunaan implan yaitu variabel umur karena variabel ini memiliki nilai $p$ paling kecil $(0,000)$ dan nilai OR paling besar $(6,39)$ dibandingkan variabel lainnya. Artinya responden yang memiliki umur 20-35 tahun berpeluang menggunakan implan sebesar 6,3 kali dibandingkan responden yang berumur $<20$ dan lebih dari $>35$.

\section{SIMPULAN}

1. Ada hubungan umur dengan penggunaan implan $(p=0,002 ; \mathrm{OR}=2,29)$.

2. Ada hubungan pendidikan dengan penggunaan implan $(p=0,000 ; \mathrm{OR}=3,62)$.

3. Ada hubungan pekerjaan dengan penggunaan implan $(p=0,012 ; \mathrm{OR}=1,98)$.

4. Ada hubungan paritas dengan penggunaan implan ( $p=0,000 ; \mathrm{OR}=2,64)$.

5. Ada hubungan jarak kelahiran dengan penggunaan implan $(p=0,004 ; \mathrm{OR}=2,28)$.

6. Ada hubungan biaya dengan penggunaan implan ( $p=0,016 ; \mathrm{OR}=1,97)$.

7. Ada hubungan jarak pelayanan dengan penggunaan implan $(p=0,000 ; \mathrm{OR}=3,39)$.

8. Variabel yang dominan berhubungan dengan penggunaan implan adalah umur dengan $p$ value $=0,000 \mathrm{OR}=6,39$.

\section{SARAN}

\section{Bagi Petugas Kesehatan}

1. Perlunya penyuluhan secara berkesinambungan tentang alat dan metode kontrasepsi, cara kerja, efek samping, efektifitas, indikasi dan kontraindikasi bagi calon akseptor dan akseptor KB aktif.

2. Tenaga kesehatan, khususnya bidan didalam melakukan konseling pemilihan kontrasepsi, diharuskan menggunakan lembar balik Alat Bantu Pengambilan Keputusan dalam Ber$\mathrm{KB}$ dengan ikut melibatkan peran serta

\section{DAFTAR PUSTAKA}

$\begin{array}{lrr}\text { BKKBN. 2008. } & \text { Faktor-faktor yang } \\ \text { Mempengaruhi } & \text { Rendahnya } & \text { Partisipasi } \\ \text { Pria } & \text { dalam } & \text { KB. } \\ \text { http:///www.bkkbn.go.id/gemapria/info- } \\ \text { detail.php?infid=79. } \\ \text { BKKBN. 2009. Studi Kualitatif Fokus Group } \\ \text { Diskusi Identifikasi Sasaran }\end{array}$

suami didalam pengambilan keputuan dalam memberikan penjelasan seputar kontrasepsi, serta mengarahkan kepada akseptor untuk menggunakan MKJP, salah satunya dengan implan.

3. Perlunya membangun informasi positif tentang KB implan, guna mengubah persepsi dan penerimaan masyarakat tentang isu yang berkembang seputar penggunaan implan, seperti implan berpindah-pindah, implan jalan, dll agar masyarakat termotivasi untuk menggunakan kontarsepsi implan.

4. Petugas pemberi pelayanan kontrasepsi diharapkan dapat memberi kemudahan bagi klien yang kurang mampu dengan memberikan pelayanan kontrasepsi implan secara cuma-cuma atau menggunakan sistem angsuran jasa pelayanan atau dengan kegiatan KB gratis.

\section{Bagi Puskesmas}

1. Perlunya dilakukan sweeping KB secara rutin setiap triwulan/semester, dengan melibatkan tenaga kesehatan dan kader kesehatan guna mengantisipasi terjadinya kehamilan diusia tua, WUS yang tergolong unmet need, dan peserta KB aktif yang drop out, sehingga dapat mengurangi resiko kematian maternal dan perinatal.

2. Perlu melakukan refreshing kompetensi dokter atau bidan dalam pemasangan dan pencabutan berbagai metode kontrasepsi khususnya MKJP, sehingga masyarakat tidak ragu untuk menggunakan kontrasepsi yang selama ini enggan dipilih oleh masyarakat.

3. Puskesmas perlu melakukan koordinasi dengan Dinas Kesehatan Kabupaten dan Dinas Pemberdayaan Perempuan dan KB untuk menggalakan program-program dan kegiatan pelayanan KB secara cuma-cuma untuk membantu masyarakat yang kurang mampu sehingga bisa menggunakan KB yang memerlukan biaya lebih seperti implan dan IUD.

tentang Partisipasi Pria dalam Keluarga Berencana dan Kesehatan Reproduksi di Propinsi Jawa Tengah dan Jawa Timur. Kerjasama Puslitbang KB dan Kesehatan Reproduksi/ Pusna dan Puslitbang KS dan PP/Pusra. Jakarta. 
BKKBN. 2013. Alat Bantu Penambilan Keputusan dalam ber-KB. Edisi 3. Jakarta.

Depkes RI. 1999. Buku Panduan Praktis Pelayanan Kontrasepsi. Direktorat Bina Kesehatan Anak Dirjen Bina Kesehatan Masyarakat. Jakarta.

Fienalia, R.A. 2012. Faktor-faktor yang Berhubungan dengan Penggunaan Metode Kontrasepsi Jangka Panjang (MKJP) DI Wilayah Kerja Puskesmas Pancoran Mas Kota Depok Tahun 2011. Skripsi. Universitas Indonesia. Jakarta.

Green, Lawrence dan Marshal. 2005. Health Program Planning an Educational and Ecological Approach. Cetakan XI. Boston Burr. Madison New York.

Hartanto. 2008. Keluarga Berencana dan Kontrasepsi. Jilid 3. Jakarta: Pustaka Sinar Harapan.
Manuaba. 2005. Ilmu Kebidanan, Penyakit Kandungan dan Keluarga Berencana untuk Pendidikan Bidan. Edisi 3. Jakarta: EGC.

Puskesmas Rawat Inap Sukabumi. 2016. Profil Puskesmas Rawat Inap Sukabumi Tahun 2015.

Prawirohardjo, S. 2011. Buku Panduan Praktis Pelayanan Kontrasepsi. Edisi 3. Jakarta: PT. Bina Pustaka.

Saifuddin. 2003. Buku Panduan Praktis Pelayanan Kontrasepsi. Jakarta: Yayasan Pustaka Sarwono Prawirohardjo.

Suratun, dkk. 2009. Pelayanan Keluarga Berencana dan Pelayanan Kontrasepsi. Jakarta: Trans Info Media.

Suprida. 2013. Hubungan antara Pendidikan dan Umur Ibu dengan Pemilihan Kontrasepsi Implan di BPS Rachmi Palembang. KTI. Akbid Bina Husada. Palembang. 